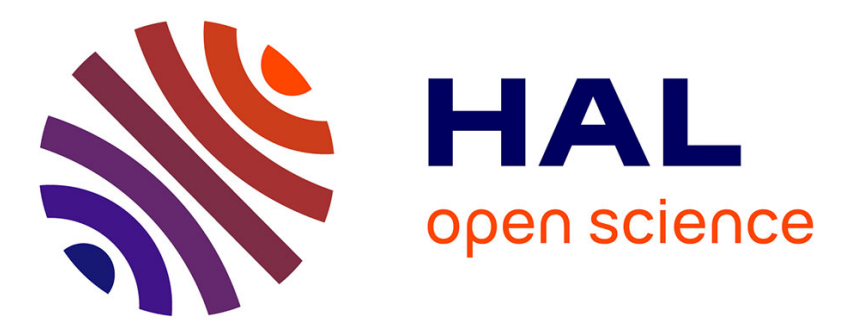

\title{
Trace element heterogeneity along isochronous growth layers in bivalve shell: consequences for environmental reconstruction
}

Claire E. Lazareth, Florence Le Cornec, Frédéric Candaudap, R. Freydier

\section{- To cite this version:}

Claire E. Lazareth, Florence Le Cornec, Frédéric Candaudap, R. Freydier. Trace element heterogeneity along isochronous growth layers in bivalve shell: consequences for environmental reconstruction. Palaeogeography, Palaeoclimatology, Palaeoecology, 2013, 373 (SI), pp.39-49. 10.1016/j.palaeo.2011.04.024 . ird-01097938

\section{HAL Id: ird-01097938 \\ https://hal.ird.fr/ird-01097938}

Submitted on 22 Dec 2014

HAL is a multi-disciplinary open access archive for the deposit and dissemination of scientific research documents, whether they are published or not. The documents may come from teaching and research institutions in France or abroad, or from public or private research centers.
L'archive ouverte pluridisciplinaire HAL, est destinée au dépôt et à la diffusion de documents scientifiques de niveau recherche, publiés ou non, émanant des établissements d'enseignement et de recherche français ou étrangers, des laboratoires publics ou privés. 


\section{Accepted Manuscript}

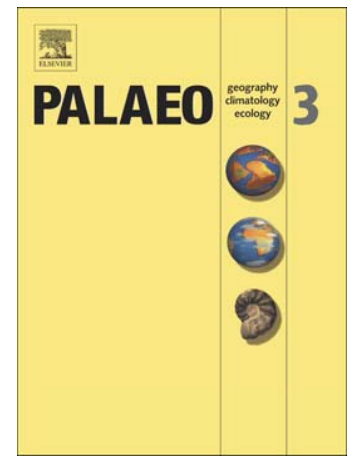

Trace element heterogeneity along isochronous growth layers in bivalve shell: Consequences for environmental reconstruction

\section{C.E. Lazareth, F. Le Cornec, F. Candaudap, R. Freydier \\ PII: $\quad$ S0031-0182(11)00226-4 \\ DOI: $\quad$ doi: $10.1016 /$ j.palaeo.2011.04.024 \\ Reference: $\quad$ PALAEO 5774}

To appear in: Palaeogeography

Received date: 19 November 2010

Revised date: $\quad 6$ April 2011

Accepted date: $\quad 22$ April 2011

Please cite this article as: Lazareth, C.E., Le Cornec, F., Candaudap, F., Freydier, R., Trace element heterogeneity along isochronous growth layers in bivalve shell: Consequences for environmental reconstruction, Palaeogeography (2011), doi: 10.1016/j.palaeo.2011.04.024

This is a PDF file of an unedited manuscript that has been accepted for publication. As a service to our customers we are providing this early version of the manuscript. The manuscript will undergo copyediting, typesetting, and review of the resulting proof before it is published in its final form. Please note that during the production process errors may be discovered which could affect the content, and all legal disclaimers that apply to the journal pertain. 
Trace element heterogeneity along isochronous growth layers in bivalve shell: Consequences for environmental reconstruction

C. E. LAZARETH ${ }^{1, *}$, F. LE CORNEC ${ }^{1}$, F. CANDAUDAP ${ }^{2}$ and R. FREYDIER ${ }^{2,3}$

${ }^{1}$ IPSL/LOCEAN, UPMC/CNRS/IRD/MNHN, Centre IRD France Nord, 32 avenue Henri Varagnat, 93143 Bondy CEDEX, France

${ }^{2}$ Géosciences Environnement Toulouse (GET), UPS/CNRS/IRD, 14 Avenue Edouard Belin, Toulouse 31400, France

${ }^{3}$ Present address: Laboratoire HydroSciences Montpellier - Université Montpellier 2 - Case MSE, Place Eugene Bataillon, 34095 Montpellier CEDEX 5

* Corresponding author. E-mail address: claire.lazareth@ird.fr (C. E. Lazareth). 


\section{ABSTRACT}

To precisely reconstruct environmental changes from high-resolution bivalve shell geochemistry, the shell layers must represent environmental conditions at the time of deposition. Therefore, calcium carbonate along growth lines that formed at the same time should show the same geochemical signature. We test this assumption by evaluating the geochemical spatial homogeneity along growth layers (i.e., shell secreted at a given time) on shell cross-sections of modern shells of the bivalve Protothaca thaca, for ontogenically young and old specimens. Analyses were carried out using laser ablation ICP-MS and solution nebulization ICP-MS. Scanning electron microscope images showed signs of early diagenesis of old shell sections (close to the umbo) compared with recent (close to the ventral margin). The spatial distribution of $\mathrm{Sr} / \mathrm{Ca}, \mathrm{Mg} / \mathrm{Ca}$ and $\mathrm{Ba} / \mathrm{Ca}$ along growth layers differed consistently between old and recent shell sections. Elemental distribution at the ventral margin of young specimens was similar for the two specimens analyzed and similar to the element distribution in the older specimens at a similar ontogenic stage (closer to the umbo). If a balancing of the shell composition with the surrounding seawater between the old and recent part of the shell, supported by diagenesis, cannot be excluded, we assume that trace element incorporation process at a given time varied with the age of the specimen, in connection with changes of mantle characteristics. Whereas $\mathrm{Ba} / \mathrm{Ca}$ and $\mathrm{Sr} / \mathrm{Ca}$ were almost constant for shell secreted at a given time close to the current ventral margin, all individuals showed significant $\mathrm{Mg} / \mathrm{Ca}$ heterogeneities, with reproducible patterns. We assumed that this would be due to a zonation of the outer epithelium of the mantle that would favor or inhibit the transport of $\mathrm{Mg}$ into the extrapallial fluid, and subsequently into the shell. Time-series obtained crossing successive growth layers using laser ablation ICP-MS and solution nebulization ICP-MS on a same-shell growth section were similar for $\mathrm{Sr} / \mathrm{Ca}$ and $\mathrm{Ba} / \mathrm{Ca}$ ratios and not for $\mathrm{Mg} / \mathrm{Ca}$, which reflected 
both the different spatial resolution of the analytical techniques and the heterogeneous distribution of $\mathrm{Mg} / \mathrm{Ca}$. In the $P$. thaca shells, $\mathrm{Sr}$ and $\mathrm{Ba}$ seemed to be most promising as potential high-resolution environmental proxies. Our study showed that the location of highresolution analyses points in shell cross-section must be i/ precisely defined and ii/ consistently followed along the shell section to provide accurate environmental records; i.e., without bias related to shell layer heterogeneities.

\section{Highlights :}

1/ Evaluation of geochemical homogeneity of isochronous growth layer on modern bivalves. 2/ SEM observation of shell dissolution on shell portion close to the umbo.

3/ Differences in trace element distribution along isochronous layer for old and recent shell section.

4/ Trace element incorporation process may vary with the age of the specimen.

5/ Mantle zonation is assumed to explain $\mathrm{Mg} / \mathrm{Ca}$ heterogeneity along isochronous layers of recent shell.

6/ High-spatial analytical technique procedure for molluscan shell study must be precisely defined.

Keywords: bivalve, shell, laser ablation, ICP-MS, trace elements 


\section{Introduction}

Variations of trace element content through time (i.e., crossing successive growth layers) in bivalve shells have been used to provide records of environmental changes (e.g. Freitas et al., 2005; Hendry et al., 2001; Price and Pearce, 1997; Takesue and van Geen, 2004; Vander Putten et al., 2000). Nevertheless, various parameters influence the trace element incorporation into bivalve shells (Ford et al., 2010; Freitas et al., 2009; Gillikin et al., 2005; Takesue et al., 2008). To better understand what is recorded in the shell, studies on the trace element distribution within a given growth layer of the shell, i.e., shell material deposited at the same given time, have been undertaken (Carré et al., 2006; Foster et al., 2008; Freitas et al., 2009; Klein et al., 1996; Rosenberg et al., 1989). Indeed, shells will be reliable tracers of the environment only when their chemical composition at a given time point is homogeneous and reflects the environment.

Previous studies of intra-shell variability have focused essentially on different shell growth axes, each characterized by a different shell growth rate. Indeed, shell growth rate is lower for an axis going from the umbo to the posterior edge than for an axis going from the umbo to the ventral margin (see Fig. 2 from Klein et al., 1996, for example). Differences in $\mathrm{Mg} / \mathrm{Ca}$ and $\mathrm{Sr} / \mathrm{Ca}$ ratios between Mytilus edulis shell portions characterized by low or high growth rate were interpreted in terms of differences in mantle metabolism (Klein et al., 1996; Rosenberg and Hughes, 1991; Rosenberg et al., 1989). Recently, Carré et al. (2006) observed different $\mathrm{Sr} / \mathrm{Ca}$ profiles in Mesodesma donacium shells between two different sections of the shell. These authors proposed a Sr incorporation model that took into account the shell "mineralization rate." Few works, however, concern the spatial distribution of the elements within the shell section made along the maximum growth axis, i.e., where the geochemical profiles for the environmental reconstitutions are carried out. In one bivalve shell section cut 
along the maximum growth axis, Carré et al. (2006) observed trace element heterogeneity within single growth layers, i.e., following an isochronous profile (Carré et al., 2006; electronic annex 2). Nevertheless, few analyses per growth layer (two in most cases) were carried out, yielding limited insight into the possible heterogeneity of trace element concentrations within the growth layer considered. Within one section of Arctica islandica, Foster et al. $(2008 ; 2009)$ realized three parallel profiles at different distances from the periostracum and observed a $\mathrm{Sr} / \mathrm{Ca}$ and $\mathrm{Mg} / \mathrm{Ca}$ decrease while moving away from the periostracum. The authors proposed that these differences are related to crystal growth mechanisms or extrapallial fluid (EPF) heterogeneity. In Mytilus edulis and Pecten maximus shells, Freitas et al. (2009) evidenced $\mathrm{Mg} / \mathrm{Ca}, \mathrm{Sr} / \mathrm{Ca}$, and $\mathrm{Mn} / \mathrm{Ca}$ heterogeneity along growth layers. To explain these heterogeneities, the authors evoked small differences in the mechanisms of element incorporation at the interface between the crystals and the EPF, or the presence of different amounts of organic matrix. These studies thus show that for a given growth layer of a given shell section, the distribution of trace elements can be heterogeneous. This means that, depending on the location where high-resolution trace element time-series analyses are carried out, even within the same section the results obtained can be different without this being due to environmental variability.

In this study, we analyzed the trace element concentration distribution along isochronous growth layers in several Protothaca thaca bivalve shells using laser ablation ICPMS (LA-ICP-MS). For three shells, the trace element spatial distribution in two growth layers, close to and far from the ventral margin, was analyzed to determine whether the trace element distribution along growth layer remains the same during the lifetime of the animal. Then, to determine if the changes observed were related to modification of the shell (i.e., the biocarbonate as material) or to the animal ageing, shells of young and old specimens were studied. Lastly, short parallel time-series profiles over the same period of shell growth were 
obtained on two shells, using LA-ICP-MS for one and LA-ICP-MS and SN-ICP-MS for the other, to examine these two techniques in connection with their application on molluscan shells in terms of paleoenvironmental reconstruction.

\section{Material and methods}

Table 1 presents a summary of the samples studied and of the geochemical analyses carried out on them.

\subsection{Samples}

Protothaca thaca (Molina, 1782) (Mollusca, Veneridae) is an upper-subtidal bivalve commonly living along the southeastern coasts of the Pacific Ocean $\left(8^{\circ}-45^{\circ} S\right)$. Adult $P$. thaca shells were collected from two locations, Pocoma in the south of Peru (17 $\left.25^{\prime} \mathrm{S}, 71^{\circ} 22^{\prime} \mathrm{W}\right)$ and El Lenguado (23 $\left.46^{\prime} \mathrm{S}, 70^{\circ} 28^{\prime} \mathrm{W}\right)$, south of Antofagasta, Chile. The Pocoma specimens (PC77, PC134) were collected alive in July and in November 2003 respectively. These specimens belonged to a population used for a growth experiment in which a sclerochronology study was performed (Lazareth et al., 2006). Two specimens of around one year old, from the same Pocoma population, were also selected (PC173, PC180). PC173 and PC180 died between August and September 2003. Shells of recently dead specimens (C00423-3, C00-423-5) were collected on a beach near Antofagasta, in 2000. The P. thaca shell is composed of two aragonite layers, an outer prismatic and an inner homogeneous layer. Hereafter, the shell part closer to the seawater will be termed the "external side of the shell" whereas the shell part in contact with, or closer to, the animal body will be called the "internal side of the shell." Shell sections, or shell growth layer, far from the ventral margin (therefore closer to the umbo, indicating that it was deposited when the animal was young) will be 
termed "old." Contrarily, shell parts, or shell growth layer, close to the ventral margin (i.e., deposited shortly before death) will be termed "recent."

Shells were sectioned along their axis of maximum growth using a water-cooled diamond saw (Isomet 5000 @, Buehler). The half-valve cross-sections were then polished, first using diamond grinding discs from 70 to $30 \mu \mathrm{m}$ grain size, and then using diamondsuspensions with decreasing grain sizes (15 to $1 \mu \mathrm{m})$ on polishing cloths. Geochemical analyses were done in the prismatic layer. For the LA-ICP-MS analyses, $0.3 \mathrm{~cm}$-thick slabs were cut from the half-valve polished cross-sections. LA-ICP-MS measurements on the C00423-3 shell were compared to conventional digestion and solution nebulization ICP-MS (SNICP-MS) results obtained on an adjacent section of the same shell, for the same growth period. To collect samples for SN-ICP-MS, a shell section of C00-423-3 was embedded in epoxy resin and a slice $\sim 5 \mathrm{~mm}$ thick was cut and polished before sampling using a microdrilling device. A scanning electronic microscope (SEM) was used to examine the microstructure of the prismatic layer. Manually broken pieces of the PC77, PC134, and C00423-3 specimens, one close to the ventral margin and one close to the umbo, were examined using a Cambridge Stereoscan SEM at $15 \mathrm{kV}$. In addition, for PC134 and C00-423-5, the microstructure of the prismatic layer was also examined at the location of the older isochronous profile (i.e., at around $1 \mathrm{~cm}$ from the ventral margin). All samples were sputtercoated with carbon before examination.

\subsection{Laser ablation analyses}

The analyses were conducted on the shell cross-sections using two sampling strategies (Fig. 1): along single growth layers, i.e., sampling shell secreted at a given time (hereaftercalled "isochronous profiles," Fig. 1b); and sampling successive shell growth layers (hereafter called "time-series profiles," Fig. 1c). The reproducibility of the time-series was examined on 
the C00-423-5 specimen doing two parallel time-series profiles on the same portion of the shell. These LA-ICP-MS profiles are located at a mean distance of $350 \mu \mathrm{m}$ (profile 1) and 600 $\mu \mathrm{m}$ (profile 2) from the external side of the shell.

Isochronous profiles were made on all specimens. To analyze shell material deposited at the same time on the shell cross-sections, we chose one darker growth line like a guide. The laser spots for the isochronous profiles were carefully placed at small distances along this noticeable growth line (i.e., the darker line was not analyzed). For PC77, PC134, and C00423-3, we made two isochronous profiles, one close to the ventral margin $(\sim 0.5 \mathrm{~cm})$, and slightly distant ( 1 cm; PC134) or far (>2 cm; C00-423-3, PC77) from the ventral margin (see Fig. 1a and Table 1). One isochronous profile at around $1 \mathrm{~cm}$ from the ventral margin was done in C00-423-5. At last, two isochronous profiles were performed in each young Pocoma specimen, at $60 \mu \mathrm{m}$ and $260 \mu \mathrm{m}$ from the ventral margin, i.e., separated from each other by $c a$. one week of shell growth. To clarify, isochronous profile close to the current ventral margin corresponds to recent shell whereas the one far from the current ventral margin corresponds to old shell. The thickness of the outer shell layer increases towards the ventral margin of the shell and differs between specimens. Consequently, to compare the isochronous profiles of the different shells, the same number was allocated to the samples located at the same relative position with respect to the inflection point of the increment considered. The $n^{\circ} 3$ was arbitrarily allocated to the laser spot the closest to the inflection point (see example in Fig. 2c). Then, numbers decreased for spots closer to the external side of the shell and increased for spots closer to the internal side of the shell. Thereby, the same number on each isochronous profile should correspond to a similar location of the mantle, the organ of the animal secreting the shell. To compare the trace element variations along isochronous profiles of the four specimens, the geochemical data were centered (i.e., mean subtracted). 
The laser was a frequency quadrupled Nd-YAG operating at $266 \mathrm{~nm}$ (LSX 200 Cetac (®) coupled with an Elan 6000 (Perkin-Elmer-SCIEX) ICP-MS from the "Laboratoire des Mécanismes de Transfert en Géologie, LMTG" (now "Géosciences Environnement Toulouse, GTE", Toulouse, France). The carrier gas was helium, mixed with argon before the plasma torch. Each laser ablation analysis was done as a single spot, and lasted between 50 and $60 \mathrm{~s}$. With the LA-ICP-MS operating conditions used (Table 2); the resulting laser holes were 62 $\mu \mathrm{m}$ in diameter. The washout time between spots was at least $30 \mathrm{~s}$. Ion sensitivity, oxide rates, and doubly charged ions were optimized each day by adjusting the plasma power, gas flows, and lens settings during ablation of the NIST-610 standard. The signal intensities of ${ }^{24} \mathrm{Mg}$, ${ }^{43} \mathrm{Ca},{ }^{88} \mathrm{Sr}$ and ${ }^{138} \mathrm{Ba}$ were recorded. To correct for daily instrumental drift, the NIST-610 was analyzed every 10 analyses. A pressed pellet of the certified otolith CRM-22 (National Institute for Environmental Studies, Japan) was analyzed every 10 to 20 samples to estimate the accuracy. The production of the CRM-22 pressed-pellet is described in Lazareth et al. (2007).

The LA-ICP-MS data processing was done using the GLITTER (C) software (van Achterbergh et al., 2001) available at the LMTG laboratory (now "Géosciences Environnement Toulouse, GTE"). The first $~ 5$ seconds were integrated and subtracted from the analytical signal (background). For signal integration, the largest window, corresponding to the more stable signal, was chosen. Usually, this corresponded to the signal between 20 and 40 s. ${ }^{43} \mathrm{Ca}$ was used as internal standard with a Ca shell content of $40 \mathrm{wt} \%$. The NIST-610 was used as external standard, using NIST-610 element concentrations from Pearce et al. (1997) to calculate the quantitative element concentrations of the unknown samples, CRM-22, and shells.

In a first data processing step, all analyses carried out on NIST-610 during one day were considered to calibrate the unknown samples. The NIST-610 concentrations calculated 
by the GLITTER@ program were then checked for instrumental drift for each daily session. If a drift of more than 5\% was observed, analyses for the considered day were split in several parts and reprocessed. After drift corrections, accuracy was checked using the CRM-22 data. Reproducibility and accuracy are in percentages, calculated on trace element concentrations in part per million. Then, element/Ca ratios were calculated assuming a constant shell Ca content of $40 \%$.

The reproducibility of LA-ICP-MS was evaluated from the mean relative standard deviation (RSD, in \%) of all certified reference material results. The shell $\mathrm{Sr}$ and $\mathrm{Ba}$ contents are close to those in CRM-22, whereas the shell $\mathrm{Mg}$ content is close to that of NIST-610. Consequently, the RSDs of Sr and Ba obtained on CRM-22 ( $\mathrm{n}=176)$ and the RSDs of Mg obtained on NIST-610 $(\mathrm{n}=259)$ were taken as representative of shell trace element measurement reproducibility. The reproducibility was $3 \%$ for $\mathrm{Mg}, 3.6 \%$ for $\mathrm{Sr}$, and $7.3 \%$ for Ba. The LA-ICP-MS accuracy was determined from CRM-22 results. Although shell reference material would have been desirable, none was available when this work started. For each analytical sequence, we calculated the difference between the measured and the reference values of CRM-22. The mean difference, expressed as a percentage, was then calculated. The mean accuracy on CRM-22 considering all sequences $(n=176)$ was $5.6 \%$ for $\mathrm{Mg}, 10.8 \%$ for $\mathrm{Sr}$, and $8.7 \%$ for $\mathrm{Ba}$.

\subsection{Solution analysis}

A part of the C00-423-3 shell, already analyzed using LA-ICP-MS, was analyzed using SNICP-MS. The solution analyses were carried out on an Ultramass Varian ${ }^{\circledR}$ ICP-MS instrument at the IPSL/LOCEAN laboratory, Centre IRD France Nord (ex-UR055Paléotropique). The operating conditions are listed in Table 3. 
Powders were taken following growth increments (curved grooves), sampling almost all the external shell layer, using a Merchantek Micromill@ device. The average width of a micro-drilled sample was $200 \pm 6 \mu \mathrm{m}$ and sampling was as continuous as possible along the shell section. The carbonate powders were dissolved in 2.5 to $5 \mathrm{ml}$ of $2 \mathrm{wt} \%$ nitric acid solution (Suprapur $65 \mathrm{wt} \%$, Merck) that contained $100 \mu \mathrm{g} . \mathrm{l}^{-1}$ of scandium, yttrium, and indium, used as internal standards. For ICP-MS calibration, standard solutions with different increasing concentrations of the analytes were prepared by appropriate dilution of monoelemental Mg, Ca, Sr, and Ba 1000 mg..$^{-1}$ certified stock solutions (Spex, Longjumeau, France) in $2 \mathrm{wt} \%$ nitric acid. One sample of the above standard solution was analyzed every 10 samples to check for instrumental drift, which was less than 5\%. The CRM-22 was analyzed every 10 samples for accuracy assessment.

Sample matrix effect and long term fluctuations were corrected using the internal standard method (Le Cornec and Corrège, 1997). Scandium was used as an internal standard for $\mathrm{Ca}$ and $\mathrm{Mg}$, yttrium for $\mathrm{Sr}$, and indium for $\mathrm{Ba}$. As the powders were not weighted, results are given as element/Ca ratios.

The Mg/Ca SN-ICP-MS ratios for micro-milled samples taken between 22 to $30 \mathrm{~mm}$ from the shell ventral margin were significantly higher than the $\mathrm{Mg} / \mathrm{Ca}$ results obtained using LA-ICP-MS in the same shell section. Analyses on additional samples milled from the same shell section confirmed that the first samples had probably been contaminated (in the tubes?). Consequently, the $\mathrm{Mg} / \mathrm{Ca}$ data between 22 to $30 \mathrm{~mm}$ were removed.

The SN-ICP-MS reproducibility was calculated from shell data. Fourteen C00-423-3 samples were analyzed two or three times. The reproducibility $(\mathrm{n}=14)$ was $2.3 \%$ for $\mathrm{Mg} / \mathrm{Ca}$, $1.4 \%$ for $\mathrm{Sr} / \mathrm{Ca}$, and $2.3 \%$ for $\mathrm{Ba} / \mathrm{Ca}$. For $\mathrm{Mg} / \mathrm{Ca}$, the reproducibility obtained here is similar to that reported by Gillikin (2005). The reproducibility for Sr/Ca was two times better than the one reported by Gillikin et al. (2005) for an in-house standard analyzed by SN-HR-ICP-MS. 
Lastly, our $\mathrm{Ba} / \mathrm{Ca}$ reproducibility was similar to that obtained on Saxidomus giganteus, and more than twice that obtained on Mytilus edulis using a SN-HR-ICP-MS (Gillikin, 2005;

Gillikin et al., 2006). Our results can thus be considered as highly reproducible. Accuracy was checked on CRM-22 ( $\mathrm{n}=5)$ and was $2.9 \%$ on $\mathrm{Mg} / \mathrm{Ca}, 0.9 \%$ on $\mathrm{Sr} / \mathrm{Ca}$, and $11 \%$ on $\mathrm{Ba} / \mathrm{Ca}$. For $\mathrm{Ba}$, the SN-ICP-MS accuracy is poor (11\%). This probably reflects that, compared to $\mathrm{Sr}$ and $\mathrm{Mg}, \mathrm{Ba}$ concentration in CRM-22 is very low (less than $0.5 \mu \mathrm{g} .1^{-1}$ in solution).

\subsection{Comparison of LA-ICP-MS and SN-ICP-MS profiles}

To compare the results obtained in C00-423-3 using LA-ICP-MS and SN-ICP-MS, sample correspondence between each shell slice analyzed must be determined. The distance from the ventral margin of the shell for each sample was measured under an optical microscope. For these measurements, we took the center point of the micro-drill grooves or laser craters. Then, for each shell slice, dark growth bands were identified. Samples taken from these easily distinguishable features were used as references to correlate the LA-ICP-MS and SN-ICP-MS profiles.

Reduced major axis regressions, using the software from Bohonak and van der Linde (2004), were carried out to compare the analytical results obtained with LA-ICP-MS and SNICP-MS.

\section{Results}

\subsection{Isochronous trace element profiles}

The patterns of the isochronous trace element profiles close to the ventral margin of the adult specimen's shells (3 profiles; corresponding to recent shell) differ according to the element considered (Fig. 2a). The Mg/Ca patterns are similar with first a decrease, then an increase, 
and subsequently another decrease moving from the external towards the internal side of the shell. These variations are significant considering the analytical precision of $3 \%$ for $\mathrm{Mg} / \mathrm{Ca}$. The Sr/Ca decreases slightly along the analyzed growth lines. Along the isochronous profiles in the PC77 and PC134 shells, the Ba/Ca decreases slightly, whereas in C00-423-3 a sharp decrease is observed towards the internal side of the shell (Fig. 2a). Trace element distributions for the isochronous profiles far from the ventral margin of the shells (corresponding to older shell) differ from those observed for the isochronous profiles close to the ventral margin. Almost all trace element ratios decrease toward the internal side of the shell (Fig. 2b). These decreases range from $33 \%$ to $70 \%$ for $\mathrm{Mg}$ and $\mathrm{Ba}$, and from $16 \%$ to $37 \%$ for Sr. Only the $\mathrm{Sr} / \mathrm{Ca}$ and $\mathrm{Ba} / \mathrm{Ca}$ patterns in C00-423-3 are different, with, from the external to the internal side of the shell, an increase for $\mathrm{Sr} / \mathrm{Ca}$ and a decrease followed by an increase for $\mathrm{Ba} / \mathrm{Ca}$. In addition, the ranges of elemental ratios are higher for isochronous profiles far from the ventral margin (e.g., $\mathrm{Mg} / \mathrm{Ca}$ from -1.0 to 1.0 around the mean) compared with ranges for isochronous profiles close to the ventral margin (e.g., $\mathrm{Mg} / \mathrm{Ca}$ from $\sim-0.2$ to +0.2 around the mean).

The trace element distribution along the four isochronous profiles done close to the ventral margin of the young Pocoma shells (PC173 and PC180) is similar for both shells and for all elements, with a decrease from the external to the internal side of the shells (Fig. 3a). The range of trace element/Ca ratio is higher for isochronous profile very close to the ventral margin of the shell (60 $\mu \mathrm{m}$ away), with higher ratios close to the external side of the shells, than that observed for the isochronous profiles at $260 \mu \mathrm{m}$ from the ventral margin. Compared with isochronous profiles done close to the ventral margin in the older specimens, the range of trace element/Ca ratio is far higher in young shells (Fig. 3a). This is particularly striking for the $\mathrm{Mg} / \mathrm{Ca}$ ratios which are comprised between -0.1 and 0.1 around the mean for the old specimens and between -0.5 and +0.6 around the mean for the young specimens. Contrarily, 
the distribution and range of trace element ratios along the isochronous profiles done close to the ventral margin of the young Pocoma shells are similar to those done far from the ventral margin in the older specimens (Fig. 3b).

\subsection{Time-series profiles}

Trace element time-series profiles were obtained on two adjacent shell slices of C00-423-3 using LA-ICP-MS and SN-ICP-MS (Fig. 4). The $\mathrm{Sr} / \mathrm{Ca}$ and $\mathrm{Ba} / \mathrm{Ca}$ profiles obtained with the two methods correlate well $\left(\mathrm{R}^{2}\right.$ of 0.69 for $\mathrm{Ba} / \mathrm{Ca}$ and 0.70 for $\left.\mathrm{Sr} / \mathrm{Ca} ; \mathrm{p}<0.001\right)$ whereas the $\mathrm{Mg} / \mathrm{Ca}$ differences between LA-ICP-MS and SN-ICP-MS are more pronounced (Fig. 4). Even if the $\mathrm{Mg} / \mathrm{Ca}$ values and variations are similar in the two profiles, the two time-series are not correlated $\left(\mathrm{R}^{2}=0.15 ; \mathrm{p}<0.001\right)$.

Two time-series profiles for the same growth period, but at different distances from the external side of the shell, were carried out on C00-423-5 using LA-ICP-MS. The two profiles obtained are highly similar (Fig. 5a). For $\mathrm{Sr} / \mathrm{Ca}$ and $\mathrm{Ba} / \mathrm{Ca}$, the determination coefficients are good $\left(\mathrm{R}^{2}=0.61\right.$ for $\left.\mathrm{Sr} ; \mathrm{p}<0.001\right)$ or very $\operatorname{good}\left(\mathrm{R}^{2}=0.95\right.$ for $\left.\mathrm{Ba} ; \mathrm{p}<0.001\right)$ and points on the scatter diagrams are close to the $1: 1$ line (Fig. 5b). For $\mathrm{Mg} / \mathrm{Ca}$, the correlation coefficient between the two LA-ICP-MS profiles is $0.72(\mathrm{p}<0.001)$ and the regression line is slightly shifted from 1:1 (Fig. 5b).

\section{4 "Recent" vs. "old" prismatic shell microstructure}

The microstructure of the prismatic shell layer was examined close to the ventral margin (i.e., recent shell) and far from the ventral margin (i.e., close to the umbo $=$ old shell). The surface of the prisms close to the ventral margin was relatively smooth, constituted by micrometersized scales (Fig. 6a \& c). Older prisms showed an altered surface; the scale edges seemed to have been slightly dissolved and the surface of the prisms was granular (Fig. $6 \mathrm{~b} \& \mathrm{~d}$ ). All 
specimens examined presented the same patterns. The microstructure of the PC134 and C00423-5 shells at around $1 \mathrm{~cm}$ from the ventral margin was well preserved.

\section{Discussion}

\subsection{Intra-shell trace element distribution along isochronous growth layers}

Few studies have examined the element distribution along individual growth layers in shell cross-sections (isochronous profiles; see Fig. 1a \& c), and even fewer have examined this for several specimens of the same species. In our Protothaca thaca shells, with the exception of C00-423-3 for $\mathrm{Sr} / \mathrm{Ca}$ and $\mathrm{Ba} / \mathrm{Ca}$, the isochronous trace element patterns are similar for individuals taken from the same site (PC77 and PC134, Pocoma) and for individuals taken from two different sites ( $700 \mathrm{~km}$ apart) on various dates (C00-423-3 and 423-5, Antofagasta-2000 vs. PC77 and PC134, Pocoma-2003). Consequently, the way the elements are distributed in the growing shell at a given time is independent of the environment; the same kind of distribution is observed for two different sites and moments. The particular element distribution observed along isochronous profiles is thus more probably specific to the bivalve species, here Protothaca thaca. A species dependency on trace element incorporation into bivalve shells was also proposed by Freitas et al. (2009) following their observation of differences in small-scale heterogeneity between Pecten maximus and Mytilus edulis.

On the other hand, patterns are different depending on the location of the isochronous profile within the same shell, in particular for $\mathrm{Mg} / \mathrm{Ca}$ and $\mathrm{Sr} / \mathrm{Ca}$ (Fig. 2; Table 1). We observed shell microstructure alteration (early diagenesis) with slight dissolution of the prisms for the old shell part (far from growing ventral margin), even on specimens collected alive (PC77 and PC134). This shell alteration might have favored some balancing of the shell composition with the surrounding seawater, the external part of the old shell becoming 
relatively enriched in trace elements. Pyritization was observed at the surface and inside living shells collected in marshes (Clark and Lutz, 1980). Inside the shells, the pyrite was located in specific places where the shells were weak (e.g., holes, fractures, zones rich in organic matter). To our knowledge, however, our study is the first to mention shell dissolution on modern seawater bivalve shells, all the more collected alive, and to show its potential impact on trace element distributions. The occurrence of such early diagenesis, and of its consequences in terms of geochemical signature of the shell, should be evaluated on other molluscan species, in particular on long-lived ones.

Nevertheless, we also observed similar trace element distribution for isochronous profiles far from the ventral margin in old altered shell (PC77 and C00-423-3) and closer to the ventral margin in more recent shell with no clear microstructure alteration (PC134; C00423-5). Therefore, early diagenesis alone is insufficient to explain the different trace element distribution along isochronous profiles done close to and far from the ventral margin. The isochronous trace element distributions and ranges at the ventral margin of the young specimens (PC173 and PC180) differ from those observed close to the ventral margin of the older specimens (Fig. 3a, Table 1), but are similar to the isochronous profiles done far from the ventral margin of the older specimens (Fig. 3). We hypothesize that the way the elements are incorporated along the growth layer (isochronous profiles) differs according to the age of the individual. Indeed, Jolly et al. (2004) showed that the outer epithelium of the mantle (responsible for shell formation) of Haliotis tuberculata has different characteristics according to the age of the animal (tubular zone more or less developed). Thus it could be that the differences observed between the isochronous profiles in the same shell (close to and far from the ventral margin) are related to an evolution of the mantle tissue during the life of the animal rather than to diagenesis. At last, one cannot exclude a redistribution of the trace elements along the isochronous layer shortly after its deposition (in the course of around one 
week) as observed on the two isochronous profiles done close to each other in each young shell (PC173, PC180; Fig. 3a). We propose that this could be related to a maturation effect as observed in teeth enamel (Balasse, 2002 and references therein; Zazzo et al., 2005) but further studies are needed to test this hypothesis.

For isochronous profiles done close to the ventral margin (i.e., recent shell), $\mathrm{Sr} / \mathrm{Ca}$ and $\mathrm{Ba} / \mathrm{Ca}$ ratios are almost constant whereas $\mathrm{Mg} / \mathrm{Ca}$ ratios vary significantly (Fig. 2a). The chemical components used to construct molluscan shell are transported into the EPF via the outer mantle epithelium (e.g., Simkiss and Wilbur, 1989; Wilbur, 1972; Wilbur and Saleuddin, 1983). The mantle and its outer epithelium are divided into zones (e.g., central and marginal or central, pallial, and marginal) with their own characteristics in terms of histology and matrix protein types (Auffret et al., 2003; Bubel, 1973; Crenshaw, 1980; Fang et al., 2008; Jolly et al., 2004; Neff, 1972; Wheeler, 1992; Wilbur, 1972). We hypothesize that some zonation in the outer epithelium may favor or limit the transport of $\mathrm{Mg}$ into the EPF, and subsequently into the forming shell (Fig. 7). Knowing that the distribution of $\mathrm{Mg} / \mathrm{Ca}$ along the isochronous profiles is similar between our Protothaca thaca shells, the places where the magnesium content is higher could correspond to specific zones, dependant on the species and on the specimen age, of the outer epithelium of the mantle. To explain heterogeneities along growth layers in Mytilus edulis and Pecten maximus shells, Freitas et al. (2009) put forth the assumption of the existence of small differences in the mechanisms of element incorporation at the interface between crystals and EPF, or of various quantities of organic matrix. Our assumption of a zonation of the outer epithelium of the mantle would confirm the first hypotheses of Freitas et al. (2009), and even specify it via a physiological explanation. Moreover, our assumption would be in favor of a very limited distance between the mantle outer epithelium cells and the forming shell, as proposed in other studies (Addadi et al., 2006; Freitas et al., 2009; Simkiss and Wilbur, 1989). Nevertheless, ultrastructural studies of the 
outer epithelium of the $P$. thaca mantle, and more specifically of the zone responsible for the prismatic shell layer deposition, are needed to validate our zonation hypothesis.

\subsection{Shell chemical sampling procedures and their consequences in terms of environmental} reconstructions

To reconstruct environmental changes that occurred during the life of the animal, successive growth layers of the shell are analyzed using relatively low-spatial analysis techniques (e.g., micromill sampling followed by SN-ICP-MS) or high-spatial resolution techniques (e.g., microprobes, LA-ICP-MS). In this study, we obtained times-series profiles on the same shell, for the same period of growth, using LA-ICP-MS and SN-ICP-MS. The resolution of the laser and that of the solution method are different. Indeed, because of the sampling procedure, a larger shell area is analyzed using SN-ICP-MS than when using LA-ICP-MS. This applies in terms of the time interval covered, due to sampling size (microdrill $200 \mu \mathrm{m} v s$. crater $60 \mu \mathrm{m}$ ), and in terms of the part of the outer shell layer sampled (almost all the outer layer is sampled using the micromill). Consequently, SN-ICP-MS analysis is less sensitive to potential heterogeneity within growth layers (= isochronous layers), contrary to the LA-ICP-MS. For $\mathrm{Sr} / \mathrm{Ca}$ and $\mathrm{Ba} / \mathrm{Ca}$, the results obtained on Protothaca thaca using SN-ICP-MS and LA-ICPMS correlate well. Similar results were obtained by Gillikin (2005) on Saxidomus giganteus. As in the Gillikin (2005) study, the elevated $\mathrm{Ba} / \mathrm{Ca}$ values that occur on small shell portions (corresponding to 3 to 4 laser points) are averaged when using SN-ICP-MS (due to the sampling procedure as mentioned above). Nevertheless, the good reproducibility observed between the two analytical methods for $\mathrm{Sr} / \mathrm{Ca}$ and $\mathrm{Ba} / \mathrm{Ca}$ in this study also reflects the good homogeneity of these element/Ca ratios along the isochronous profiles. Contrarily, for $\mathrm{Mg} / \mathrm{Ca}$, the correlation between the two analytical methods is poor. Gillikin (2005) made a similar observation and concluded that the certified material used for LA-ICP-MS calibration was 
inadequate (glass instead of a shell). Even if a similar conclusion can be drawn here (the NIST-610 was used for trace element LA-ICP-MS data calibration), an additional explanation can be put forward. Indeed, the $\mathrm{Mg} / \mathrm{Ca}$ fluctuations observed along the isochronous growth layers in $P$. thaca, captured by the LA-ICP-MS but not by the SN-ICP-MS method, certainly contribute to the poor correlation obtained between the two methods. Two conclusions arise from these results, i/ the LA-ICP-MS procedure provides accurate data and ii/ similar $\mathrm{Sr} / \mathrm{Ca}$ and $\mathrm{Ba} / \mathrm{Ca}$ time-series are obtained using relatively low-spatial resolution or high-spatial resolution analytical techniques, whereas $\mathrm{Mg} / \mathrm{Ca}$ shell growth layer heterogeneities complicate high-spatial resolution sampling procedure of the shell.

Although SN-ICP-MS analyses provide accurate results, this procedure is time consuming. Moreover, when sampling shells using micromill, the spatial (and thus the temporal) resolution is reduced, which can be limiting, in particular to obtain paleoenvironmental records with a high temporal resolution from slow-growing mollusks. We thus further evaluated the LA-ICP-MS sampling procedure on two time-series profiles realized on the same growth period but at different distances from the external side of the C00-423-5 shell. The $\mathrm{Sr} / \mathrm{Ca}$ and $\mathrm{Ba} / \mathrm{Ca}$ shell changes through time are reproducible. Consequently, environmental or paleo-environmental reconstructions based on high-spatial resolution $\mathrm{Sr} / \mathrm{Ca}$ and $\mathrm{Ba} / \mathrm{Ca}$ time-series profiles on Protothaca thaca shells will not suffer from bias related to the location of the analyzes with respect to the external side of the shell. These elements could thus be used as potential proxies for environmental changes (e.g., salinity, productivity), but only if an accurate relationship between environmental parameters can be established. Indeed, if the $\mathrm{Ba} / \mathrm{Ca}$ potential as environmental tracer in bivalve shells has been shown in some species (Barats et al., 2009; Gillikin et al., 2006; Gillikin et al., 2008; Thébault et al., 2009), the use of $\mathrm{Sr} / \mathrm{Ca}$ as tracer of environmental changes seems compromised (Foster et al., 2009; Gillikin et al., 2005; Takesue and van Geen, 2004). 
For $\mathrm{Mg} / \mathrm{Ca}$, the deviation from 1:1 of the slope of the regression line between the two LA-ICP-MS time-series (made at a different distance from the external side of the shell) clearly reflects the $\mathrm{Mg} / \mathrm{Ca}$ isochronous heterogeneity. The validity of environmental data extracted from high-spatial resolution $\mathrm{Mg} / \mathrm{Ca}$ analyses, at least in Protothaca thaca, is thus highly dependent on the careful location of the high-resolution analyses. One must locate the analysis points at the same relative position with respect to the thickness of the shell layer considered; e.g., always with $1 / 3$ the thickness relative to the external part of the shell. Still, this procedure is appropriate only for shell parts where trace element distribution along a single growth layer remains the same. Concerning $\mathrm{Mg} / \mathrm{Ca}$, the complexity of its incorporation in the shell at a given moment shown in this study might provide additional clues to explain the difficulties encountered for the calibration of a SST proxy based on $\mathrm{Mg} / \mathrm{Ca}$ in molluscan shells (e.g., Surge and Lohmann, 2008; Wanamaker Jr et al., 2008). Before interpreting shell geochemistry in terms of environmental changes, shell growth layer homogeneity, on the shell cross-section chosen, should be assessed for recent (close to the ventral margin) and old (closer to the umbo) shell section, and this more particularly concerning $\mathrm{Mg} / \mathrm{Ca}$ records.

\section{Acknowledgments}

This work was partly supported by the UR055 - PALEOTROPIQUE (IRD) (now IPSLLOCEAN) and the "CONCHAS" project ("Programme National d'Etude de la Dynamique du Climat", INSU, France). This study was also financed and conducted in the frame of the EUproject CENSOR (Climate Variability and El Nino Southern Oscillation: Implications for Natural Resources and Management, contract 511071). We deeply thank E. Grossman for his review of a first version of this paper that greatly improved the manuscript. Thanks are extended to P. Freitas, J. Thébault, and D. P. Gillikin, who provided highly detailed and 
pertinent reviews that significantly improved the final manuscript. We are also particularly grateful to E. Versteegh and F. Dehairs for language corrections and constructive comments. We thank S. Zevallos (Pocoma), L. El Jouhari, N. Guzmán and students (Facultad de Recursos del Mar, University of Antofagasta) for the realization and follow-up of the shell growth experiment, and L. Ortlieb for providing the Antofagasta shells. 


\section{References}

Addadi, L., Joester, D., Nudelman, F., Weiner, S., 2006. Mollusk shell formation: A source of new concepts for understanding biomineralization processes. Chemistry - A European Journal 12, 980-987.

Auffret, M., Barillé, L., Besnard-Cochennec, N., Blanc, F., Eve, B.-C., Chollet, B., Henry, M., Jabbour-Zahab, R., Le Pennec, M., Lubet, P., Mathieu, M., Thielley, M., 2003. Atlas d'histologie et de cytologie des mollusques bivalves marins. An altas of histology and cytology of marine bivalve molluscs. Ifremer, Brest.

Balasse, M., 2002. Reconstructing dietary and environmental history from enamel isotopic analysis: Time resolution of intra-tooth sequential sampling. International Journal of Osteoarchaeology $12(3), 155-165$.

Barats, A., Amouroux, D., Chauvaud, L., Pécheyran, C., Lorrain, A., Thébault, J., Church, T.M., Donard, O.F.X., 2009. High frequency Barium profiles in shells of the Great Scallop Pecten maximus: a methodical long-term and multi-site survey in Western Europe. Biogeosciences 6, 157-170.

Bohonak, A.J., van der Linde, K., 2004. RMA: Software for Reduced Major Axis regression. Java Version 1.19. Available at http://www.kimvdlinde.com/professional/programming/statistics/rma.html (accessed 19 November 2007).

Bubel, A., 1973. An electron-microscope investigation of the cells lining the outer surface of the mantle in some marine molluscs. Marine Biology 21 (3), 245-255.

Carré, M., Bentaleb, I., Bruguier, O., Ordinola, E., Barrett, N.T., Fontugne, M., 2006. Calcification rate influence on trace element concentrations in aragonitic bivalve shells: Evidences and mechanisms. Geochimica et Cosmochimica Acta 70 (19), 49064920. 
Clark, G.R., II, Lutz, R.A., 1980. Pyritization in the shells of living bivalves. Geology 8 (6), $268-271$.

Crenshaw, M.A., 1980. Mechanisms of shell formation and dissolution. In: Rhoads, D.C., Lutz, R.A. (Eds.), Skeletal Growth of Aquatic Organisms: Biological Record of Environmental change. Plenum Press New-York, pp. 115-132.

Fang, Z., Feng, Q.L., Chi, Y.Z., Xie, L.P., Zhang, R.Q., 2008. Investigation of cell proliferation and differentiation in the mantle of Pinctada fucata (Bivalve, Mollusca). Marine Biology 153 (4), 745-754.

Ford, H.L., Schellenberg, S.A., Becker, B.J., Deutschman, D.L., Dyck, K.A., Koch, P.L., 2010. Evaluating the skeletal chemistry of Mytilus californianus as a temperature proxy: Effects of microenvironment and ontogeny. Paleoceanography 25 (PA1203), doi:10.1029/2008PA001677.

Foster, L.C., Allison, N., Finch, A.A., Andersson, C., 2009. Strontium distribution in the shell of the aragonite bivalve Arctica islandica. Geochemistry Geophysics Geosystems 10 (Q03003), doi:10.1029/2007GC001915.

Foster, L.C., Finch, A.A., Allison, N., Andersson, C., Clarke, L.J., 2008. Mg in aragonitic bivalve shells: Seasonal variations and mode of incorporation in Arctica islandica. Chemical Geology 254 (1-2), 113-119.

Freitas, P., Clarke, L.J., Kennedy, H., Richardson, C., Abrantes, F., 2005. Mg/Ca, Sr/Ca, and stable-isotope $\left(\delta^{18} \mathrm{O}\right.$ and $\left.\delta^{13} \mathrm{C}\right)$ ratio profiles from the fan mussel Pinna nobilis: Seasonal records and temperature relationships. Geochemistry, Geophysics, Geosystems 6 (Q04D14), doi:10.1029/2004GC000872.

Freitas, P.S., Clarke, L.J., Kennedy, H., Richardson, C.A., 2009. Ion microprobe assessment of the heterogeneity of $\mathrm{Mg} / \mathrm{Ca}, \mathrm{Sr} / \mathrm{Ca}$ and $\mathrm{Mn} / \mathrm{Ca}$ ratios in Pecten maximus and 
Mytilus edulis (bivalvia) shell calcite precipitated at constant temperature.

Biogeosciences 6, 1209-1227.

Gillikin, D.P., 2005. Geochemistry of marine bivalve shells: the potential for paleoenvironmental reconstruction. $\mathrm{PhD}$ thesis, Vrije Universiteit Brussel.

Gillikin, D.P., Dehairs, F., Lorrain, A., Steenmans, D., Baeyens, W., André, L., 2006. Barium uptake into the shells of the common mussel (Mytilus edulis) and the potential for estuarine paleo-chemistry reconstruction. Geochimica et Cosmochimica Acta 70, 395407.

Gillikin, D.P., Lorrain, A., Navez, J., Taylor, J.W., André, L., Keppens, E., Baeyens, W., Dehairs, F., 2005. Strong biological controls on Sr/Ca ratios in aragonitic marine bivalve shells. Geochemistry, Geophysics, Geosystems 6 (Q05009), doi:10.1029/2004GC000874.

Gillikin, D.P., Lorrain, A., Paulet, Y.-M., André, L., Dehairs, F., 2008. Synchronous barium peaks in high-resolution profiles of calcite and aragonite marine bivalve shells. GeoMarine Letters 1-8, DOI 10.1007/s00367-008-0111-9.

Hendry, J.P., Perkins, W.T., Bane, T., 2001. Short-term environmental change in a Jurassic lagoon deduced from geochemical trends in aragonite bivalve shells. GSA Bulletin $113(6), 790-798$.

Jolly, C., Berland, S., Milet, C., Borzeix, S., Lopez, E., Doumenc, D., 2004. Zonal localization of shell matrix proteins in mantle of Haliotis tuberculata (Mollusca, Gastropoda). Marine Biotechnology 6 (6), 541-551.

Klein, R.T., Lohman, K.C., Thayer, C.W., 1996. Sr/Ca and ${ }^{13} \mathrm{C} /{ }^{12} \mathrm{C}$ ratios in skeletal calcite of Mytilus trossulus: covariation with metabolic rate, salinity, and carbon isotopic composition of seawater. Geochimica et Cosmochimica Acta 60, 4207-4221. 
Lazareth, C.E., Guzmán, N., Poitrasson, F., Candaudap, F., Ortlieb, L., 2007. Nyctemeral variations of magnesium intake in the calcitic layer of a Chilean mollusc shell (Concholepas concholepas, Gastropoda). Geochimica et Cosmochimica Acta 71 (22), 5369-5383.

Le Cornec, F., Corrège, T., 1997. Determination of uranium to calcium and strontium to calcium ratios in corals by inductively coupled plasma mass spectrometry. Journal of Analytical Atomic Spectrometry 12 (9), 969-973.

Neff, J.M., 1972. Ultrastructure of the outer epithelium of the mantle in the clam Mercenaria mercenaria in relation to calcification of the shell. Tissue Cell 4 (4), 591-600.

Pearce, N.J.G., Perkins, W.T., Westgate, J.A., Gorton, M.P., Jackson, S.E., Neal, C.R., Chenery, S.P., 1997. A compilation of new and published major and trace element data for NIST SRM 610 and NIST SRM 612 glass reference materials. Geostandards Newsletter 21, 115-144.

Price, G.D., Pearce, N.J.G., 1997. Biomonitoring of pollution by Cerastoderma edule from the British Isles: a laser ablation ICP-MS study. Marine Pollution Bulletin 34, 1025 1031.

Rosenberg, G.D., Hughes, W.W., 1991. A metabolic model for the determination of shell composition in the bivalve mollusc, Mytilus edulis. Lethaia 24 (1), 83-96.

Rosenberg, G.D., Hughes, W.W., Trachuck, R.D., 1989. Shell form and metabolic gradients in the mantle of Mytilus edulis. Hydrobiologica 22, 343-344.

Simkiss, K., Wilbur, K., 1989. Biomineralization. Cell biology and mineral deposition. Academic Press, San Diego.

Surge, D., Lohmann, K.C., 2008. Evaluating Mg/Ca ratios as a temperature proxy in the estuarine oyster, Crassostrea virginica. Journal of Geophysical Research 113 (G02001), doi:10.1029/2007JG000623. 
Takesue, R.K., Bacon, C.R., Thompson, J.K., 2008. Influences of organic matter and calcification rate on trace elements in aragonitic estuarine bivalve shells. Geochimica et Cosmochimica Acta 72 (22), 5431-5445.

Takesue, R.K., van Geen, A., 2004. Mg/Ca, Sr/Ca, and stable isotopes in modern and Holocene Protothaca staminea shells from a northern California coastal upwelling region. Geochimica et Cosmochimica Acta 68 (19), 3845-3861.

Thébault, J., Chauvaud, L., L'Helguen, S., Clavier, J., Barats, A., Jacquet, S., Pécheyran, C., Amouroux, D., 2009. Barium and molybdenum records in bivalve shells: Geochemical proxies for phytoplankton dynamics in coastal environments? Limnology and Oceanography 54 (3), 1002-1014.

van Achterbergh, E., Ryan, C., Jackson, S.E., Griffin, W.L., 2001. Appendix 3 Data reduction software for LA-ICP-MS. In: Sylvester, P.J. (Ed.) Laser Ablation-ICPMS in the Earth Sciences, pp. 239-243.

Vander Putten, E., Dehairs, F., Keppens, E., Baeyens, W., 2000. High resolution distribution of trace elements in the calcite shell layer of modern Mytilus edulis: Environmental and biological controls. Geochimica et Cosmochimica Acta 64 (6), 997-1011.

Wanamaker Jr, A.D., Kreutz, K.J., Wilson, T., Borns Jr, H.W., Introne, D.S., Feindel, S., 2008. Experimentally determined $\mathrm{Mg} / \mathrm{Ca}$ and $\mathrm{Sr} / \mathrm{Ca}$ ratios in juvenile bivalve calcite for Mytilus edulis : implications for paleotemperature reconstructions. Geo-Marine Letters 28 (5-6), 359-368.

Wheeler, A.P., 1992. Mechanisms of molluscan shell formation. In: Bonucci, E. (Ed.) Calcification in Biological Systems. CRC press New York, pp. 179-216.

Wilbur, K.M., 1972. Shell formation in mollusks. In: Florkin, M., Scheer, B.T. (Eds.), Chemical Zoology. Academic Press New-York \& London, pp. 103-145. 
Wilbur, K.M., Saleuddin, A.S.M., 1983. Shell Formation. In: Saleuddin, A.S.M., Wilbur, K.M. (Eds.), The Mollusca, Physiology, Part 1. Academic Press New York, pp. 235287.

Zazzo, A., Balasse, M., Patterson, W.P., Patterson, P., 2005. High-resolution $\delta^{13} \mathrm{C}$ intratooth profiles in bovine enamel: Implications for mineralization pattern and isotopic attenuation. Geochimica et Cosmochimica Acta 69 (14), 3631-3642. 


\section{Figure captions}

Figure 1. Illustration of the procedures followed for the high-spatial resolution intra-shell geochemistry study carried out in the Protothaca thaca specimens. (A) Three-dimensional diagram of a shell cross-section showing the isochronous (open circles) and the time-series (filled circle) laser-ablation ICP-MS profiles (not to scale). The numbers correspond to the isochronous profiles realized close to (1) and far from (2) the ventral margin, corresponding to recent and old shell respectively. Ext.: external side of the shell; Int.: internal side of the shell. (B) Example of a laser-ablation ICP-MS isochronous profile. Scale bar: $200 \mu \mathrm{m}$ (optical microscope, diffuse light). (C) Example of a laser-ablation ICP-MS times-series profile (optical microscope, diffuse light).

Figure 2. Trace element distributions (LA-ICP-MS) along isochronous profiles done in the different Protothaca thaca shells (centered element/Ca ratios). "Ext." and "Int.": external and internal side of the outer shell layer. (A) Isochronous profiles close to the ventral margin (i.e., recent shell) (B) Isochronous profiles far from the ventral margin (i.e., old shell). See Table 1 for details. (C) Close up of C00-423-3 (left) and PC134 (right) isochronous profiles (thick slide, optical microscope, diffused light). Black numbers correspond to actual laser craters; white numbers are fictive laser craters that illustrate the choice of numbering to compare the different isochronous profiles (see text for details).

Figure 3: Comparison of the trace element distributions (LA-ICP-MS) along isochronous profiles between the young and the old Protothaca thaca specimens (centered element/Ca ratios). "Ext." and "Int.": external and internal side of the outer shell layer. (A) Isochronous 
profiles done close to the ventral margin. (B) Isochronous profiles done far from the ventral margin (i.e., old specimens only; see Table 1 and Fig. 7).

Figure 4. Comparison of the LA-ICP-MS and SN-ICP-MS trace element variations from time-series profiles on the same growth period on two adjacent slices of the C00-423-3 shell. (A) Time-series trace elements content variations. (B) Correlations between the two analytical results using reduced major axis regression software from Bohonak and van der Linde (2004).

Figure 5. Comparison of LA-ICP-MS trace element variations of two time-series performed on the same portion of the C00-423-5 shell, at a different distance from the external side of the shell. (A) Time-series trace elements content variations. (B) Correlations between the two LA-ICP-MS profiles using reduced major axis regression, software from Bohonak and van der Linde (2004).

Figure 6. Scanning electron microscope images of recent and old outer (prismatic) layer of the Protothaca thaca shell (specimen PC77). (A) and (C) Prisms close to the ventral margin; i.e., recent shell. The surface of the prisms is regular and composed of micrometer scales. P: one prism. S: micrometric scale at the surface of the prisms. The white spots on the picture A are small remains remained following the preparation. (B) and (D) Prisms far from the ventral margin; i.e., old shell. The surface of the prisms is granular (see picture B) because of slight dissolution (arrows on D). H: micro boring holes.

Figure 7. Schematic representation of the mantle zonation hypothesis and of the resulting $\mathrm{Mg}$ distribution along isochronous growth layer in Protothaca thaca shells. Ext. external side of the shell; Int.: Internal side of the shell. (A) Picture of a young and of an older Protothaca 
thaca shell section (common scale). (B) Sketch of the margin of a shell (grey) with its secreting mantle and extrapallial fluid (blue). Red line: mantle epithelium; OE: outer epithelium; IE: inner epithelium; M: mantle. AB: animal body. (C) and (D) Enlargement of the margin of an old specimen and $\mathrm{Mg}$ distribution observed in an old (C) and young (D) specimen. Sketch color and legend as in (B); detail of the Mg results in the text and in Figure 3. Arrows represent the amount of $\mathrm{Mg}$ going through the external epithelium to the EPF and shell. Black slashes on the outer epithelium represent the hypothetic mantle zonation; the more they are tightened, the more there is magnesium in the shell. 
Table 1: Summary of the Protothaca thaca shells studied and of the geochemical analyses carried out. When unspecified, analyses were done using LA-ICP-MS. M, U: location of the isochronous profile relative to the ventral margin of the shells. M: close to the ventral margin; $\mathrm{U}$ : far from the ventral margin (i.e., closer to the umbo). The number in brackets is the distance from the ventral margin. For the C00-423-5 specimen, the measures specified for the time-series profiles correspond to the distance between the external side of the shell and the time-series profile considered. See text for details.

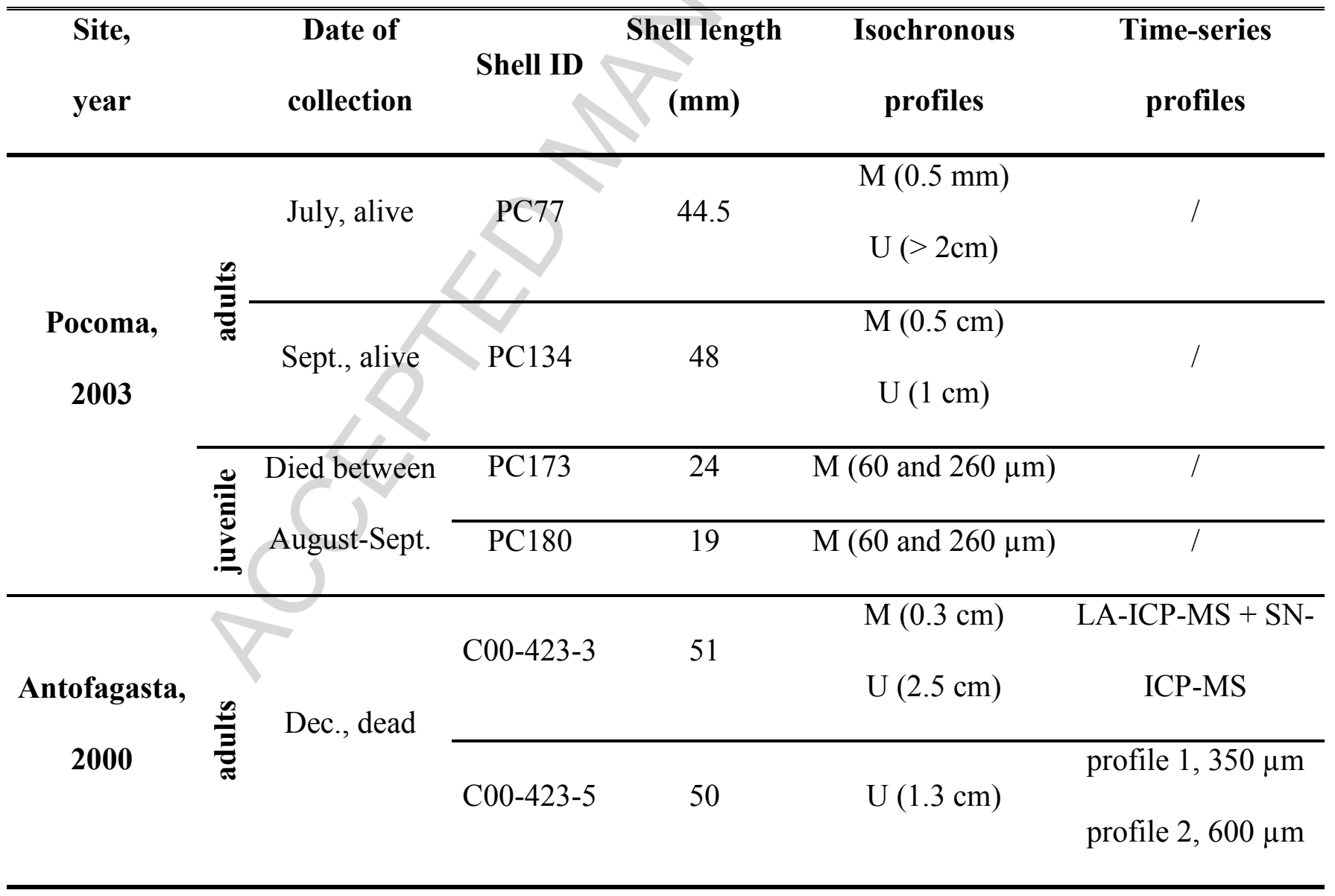

Table 2: Laser probe operating conditions. 


\section{Laser}

Wavelength

$266 \mathrm{~nm}$

Laser mode

Q-switched

Laser power

$5 \mathrm{~mJ}$

Frequency

$10 \mathrm{~Hz}$

Preablation time (blank) 6-8 s

Acquisition time (laser

firing)

$50-60 \mathrm{~s}$

Defocusing

$5 \mu \mathrm{m} . \mathrm{s}-1$

Aperture

4

Objective

$10 \mathrm{x}$

\section{ICP-MS (Elan 6000) Plasma parameters}

Power $(\mathrm{kW}) \quad 1.3$

Gas flows (1.min-1)

$\begin{array}{ll}\text { Plasma } & 15 \\ \text { Auxiliary } & 1.2 \\ \text { Carrier Ar } & 0.5 \\ \text { Carrier He } & 0.5\end{array}$

Acquisition parameters

Acquisition protocol Time Resolved Analysis

Scanning mode $\quad$ Peak hopping, 1 point per peak

Isotopes determined $\quad{ }^{24} \mathrm{Mg},{ }^{25} \mathrm{Mg},{ }^{42} \mathrm{Ca},{ }^{43} \mathrm{Ca},{ }^{88} \mathrm{Sr},{ }^{138} \mathrm{Ba}$

Dwell time per isotope $10 \mathrm{~ms}$ 
Sweeps / Readings 1

Readings / Replicate $\quad 350$

Numbers of replicate $\quad 1$

Blanc analysis $\quad 5 \mathrm{~s}$

Analysis time $\quad 60 \mathrm{~s}$

Table 3: ICP-MS plasma operating conditions and acquisition parameters.

\section{ICP-MS for solution analyses}

\begin{tabular}{cc}
\hline Plasma parameters & \\
\hline Power $(\mathrm{kW})$ & 1.25 \\
Gas flows (l.min-1) & $16-1.5$ \\
Plasma & \\
Auxiliary & \\
Carrier Ar & \\
Carrier He & 0.89 \\
Nebulization &
\end{tabular}

\section{Acquisition parameters}

\begin{tabular}{ll}
\hline Acquisition protocol & Time Resolved Analysis \\
\hline Scanning mode & Peak hopping, 1 point per peak \\
\hline Isotopes determined & ${ }^{24} \mathrm{Mg},{ }^{25} \mathrm{Mg},{ }^{42} \mathrm{Ca},{ }^{43} \mathrm{Ca},{ }^{88} \mathrm{Sr},{ }^{138} \mathrm{Ba}$ \\
\hline Dwell time per isotope (ms) & $10(\mathrm{Mg}, \mathrm{Ba})-5$ (others) \\
\hline Scans per replicate & 100 \\
\hline Number of replicate & 3 \\
\hline
\end{tabular}




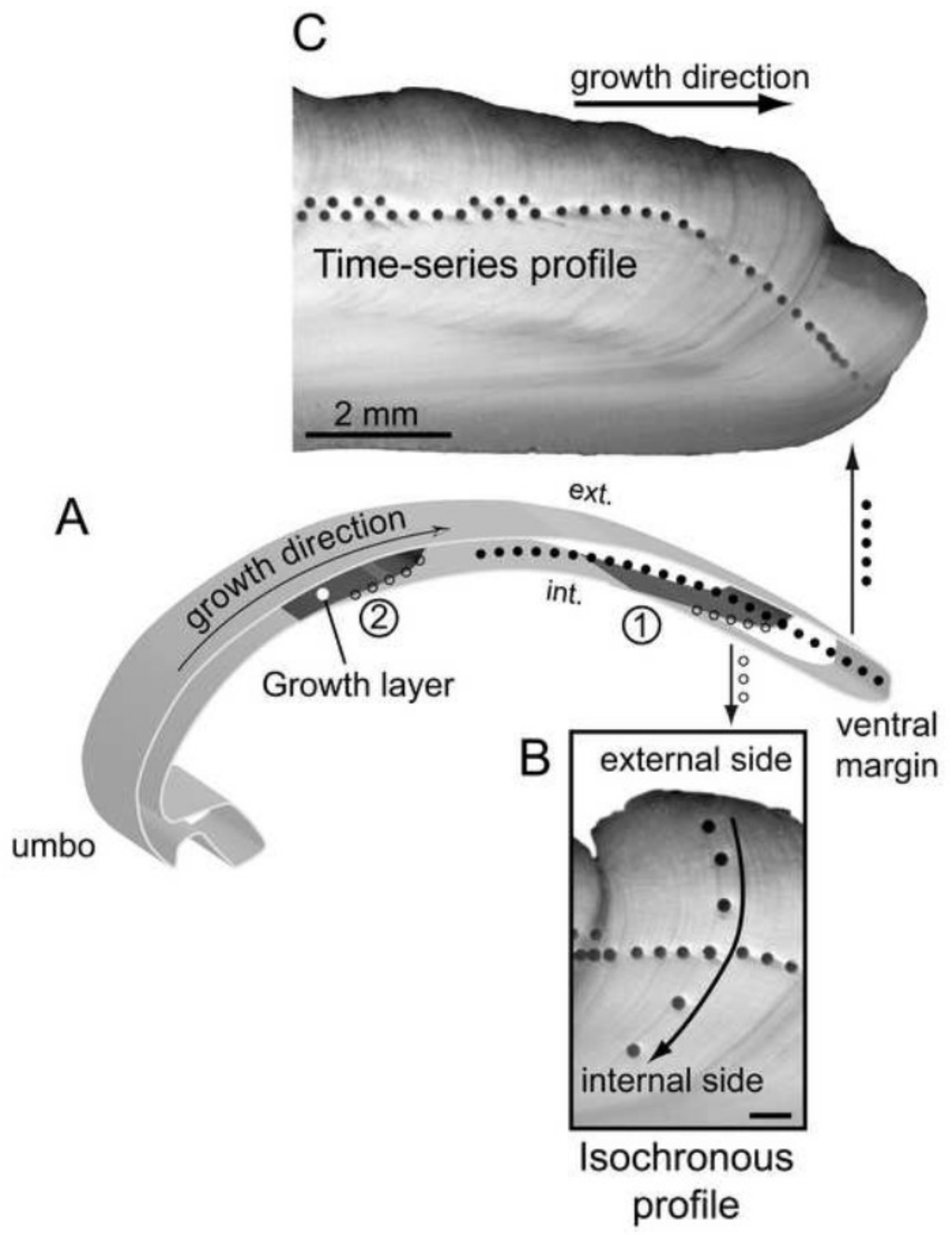

Fig. 1 

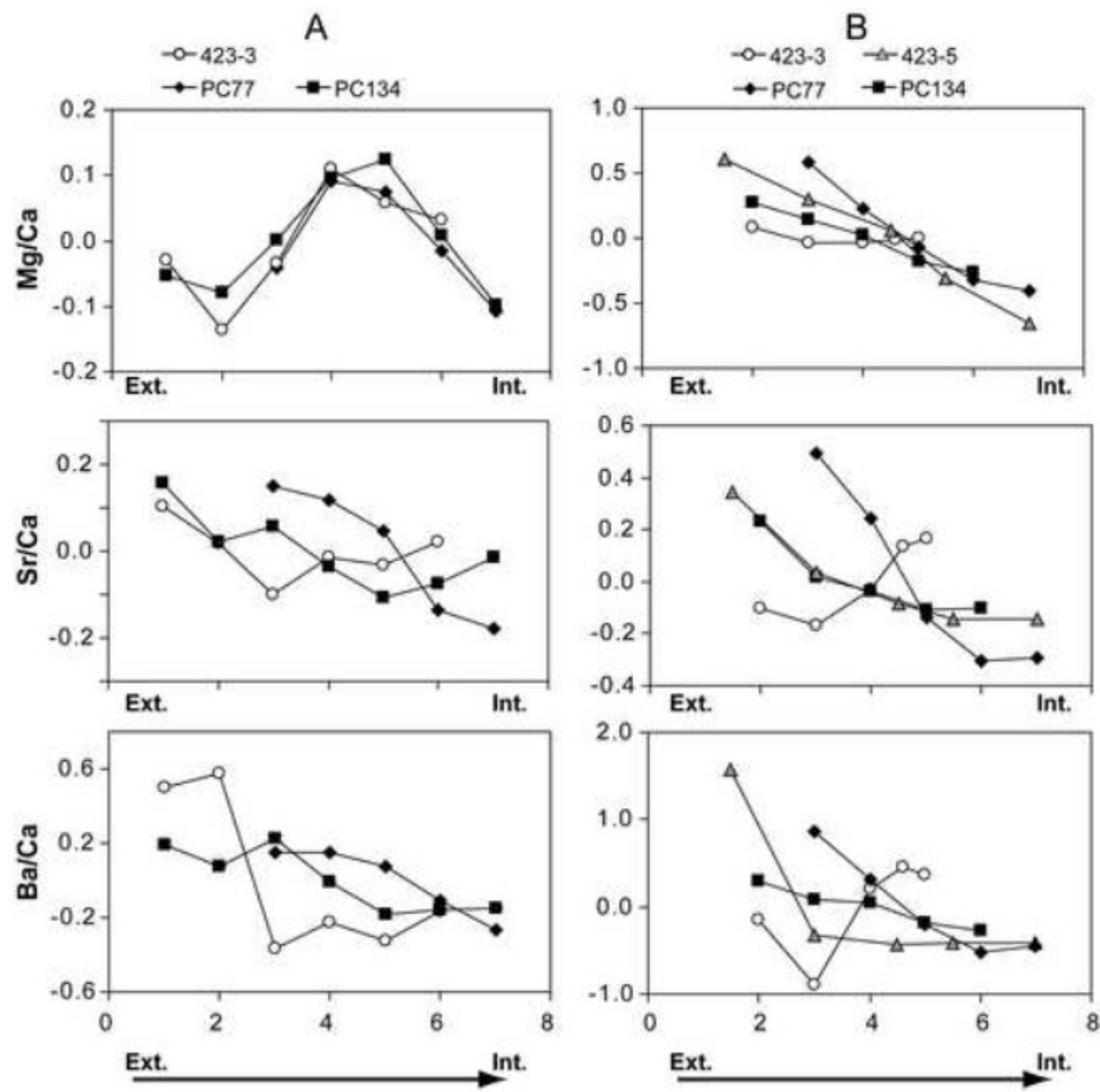

C
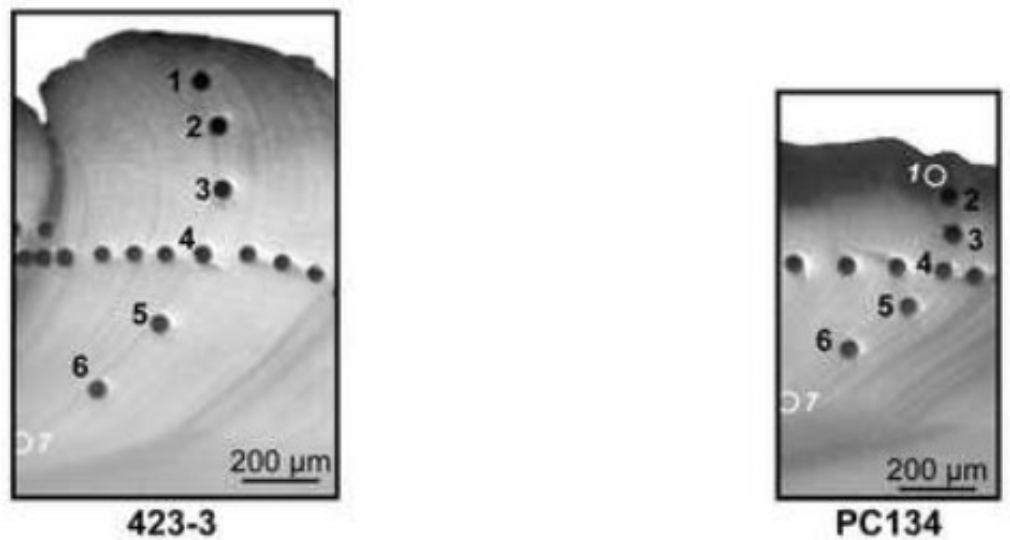

Fig. 2 
A: close to the ventral margin
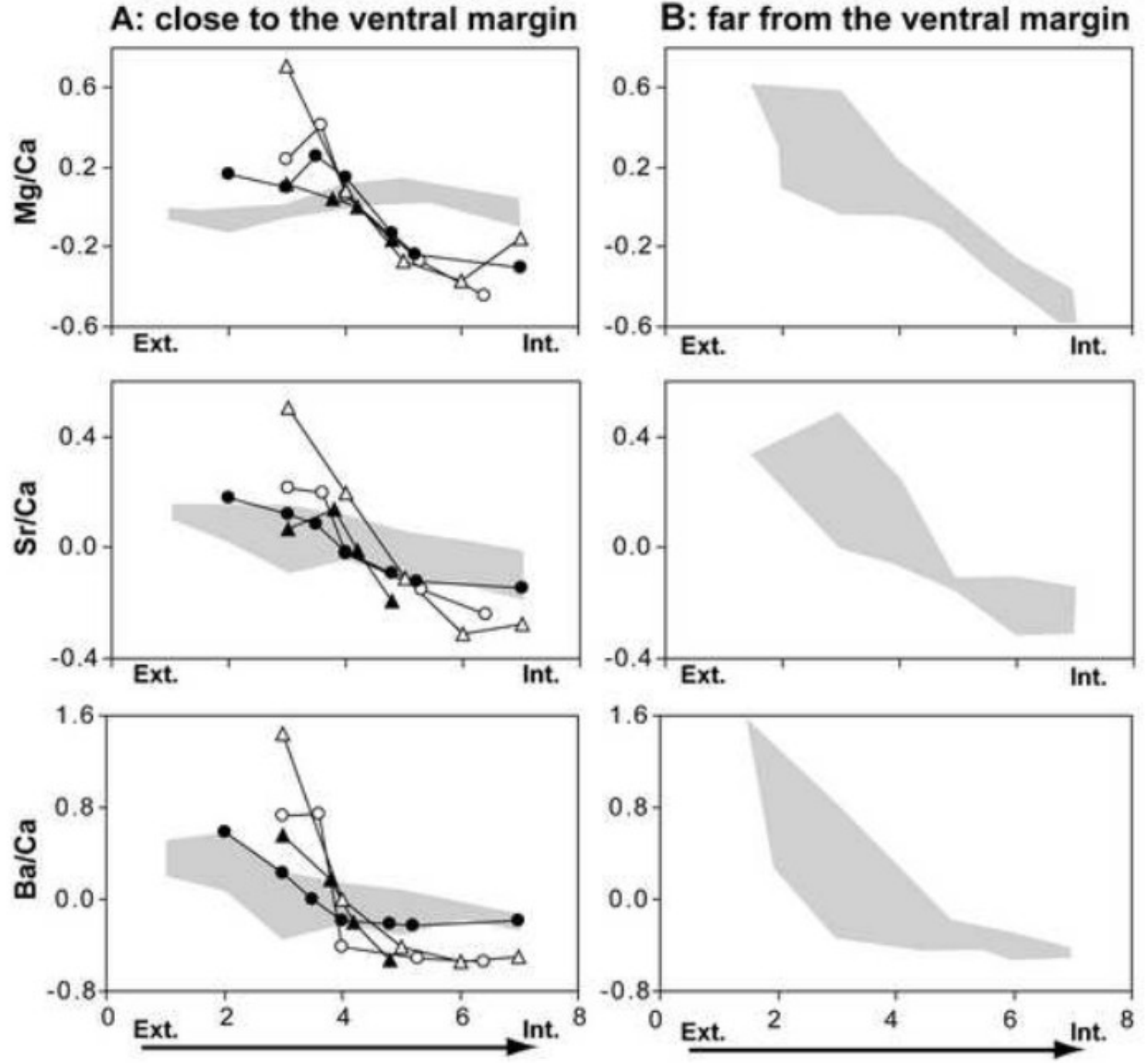

Young specimens

$-\mathrm{O}-60 \mu \mathrm{m}$ from ventral margin $\triangle-$

- $260 \mu \mathrm{m}$ from ventral margin -

Fig. 3 

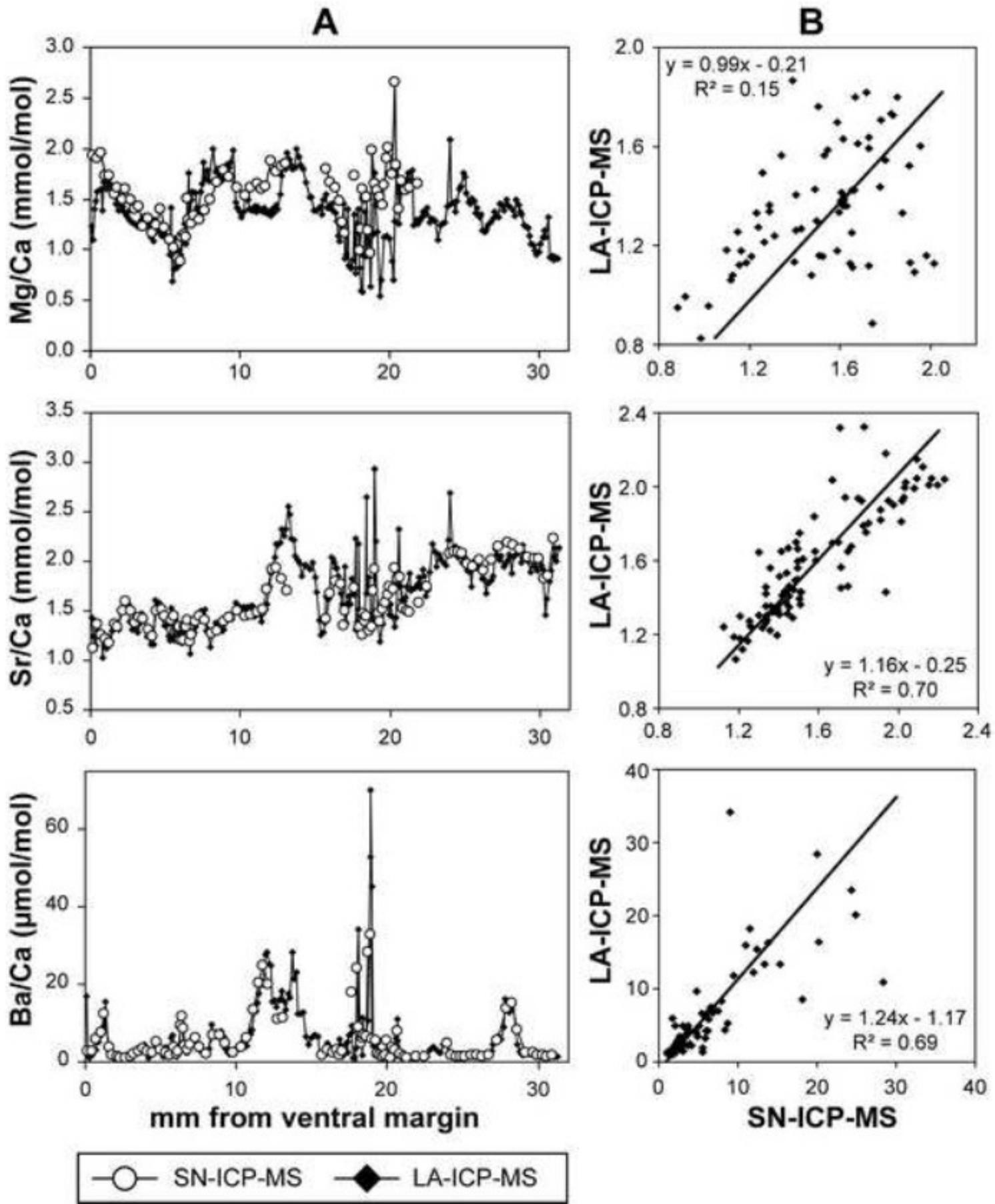

Fig. 4 

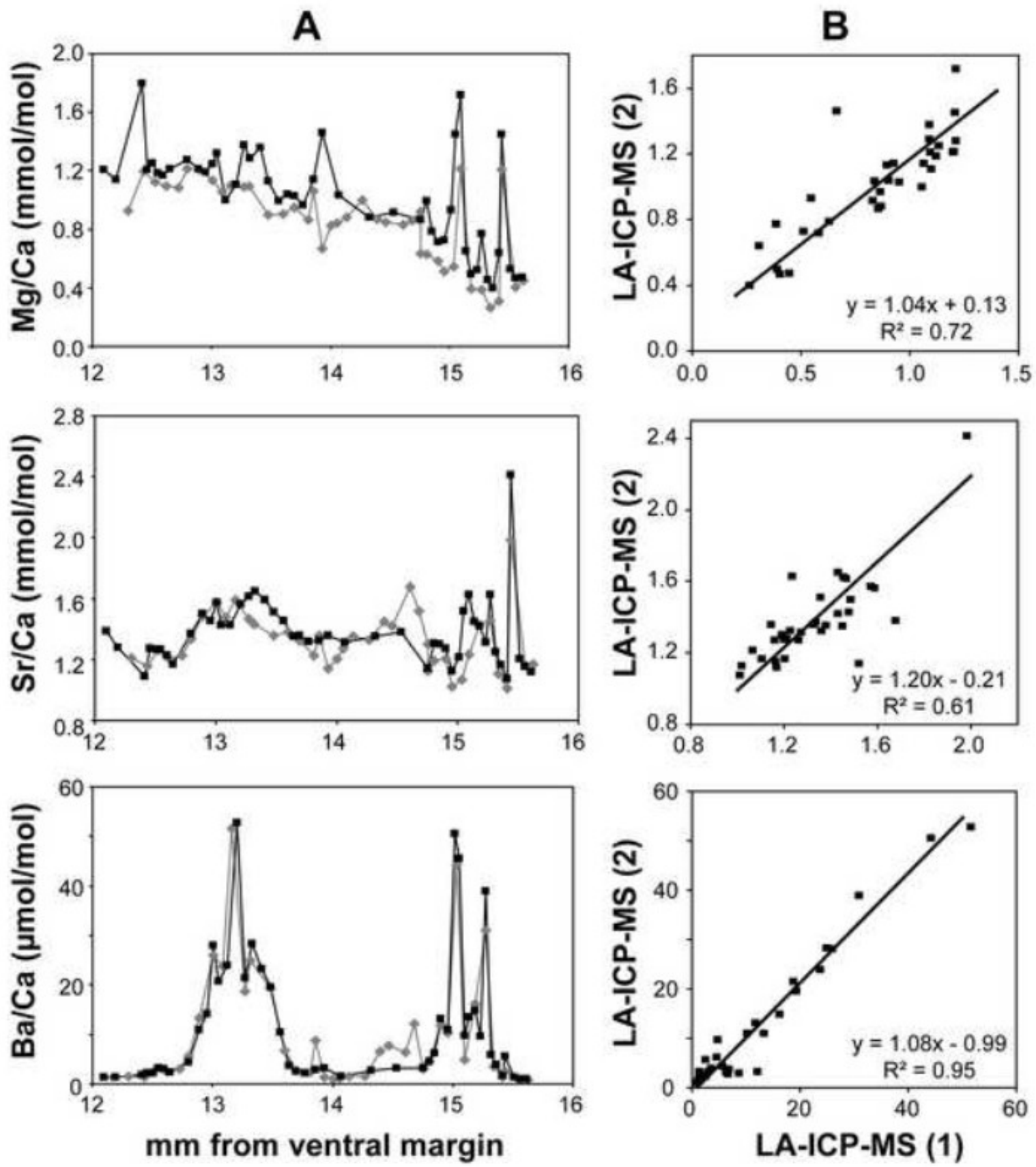

- profile 1, $350 \mu \mathrm{m}$ from the external side of the shell profile $2,600 \mu \mathrm{m}$ from the external side of the shell

Fig. 5 

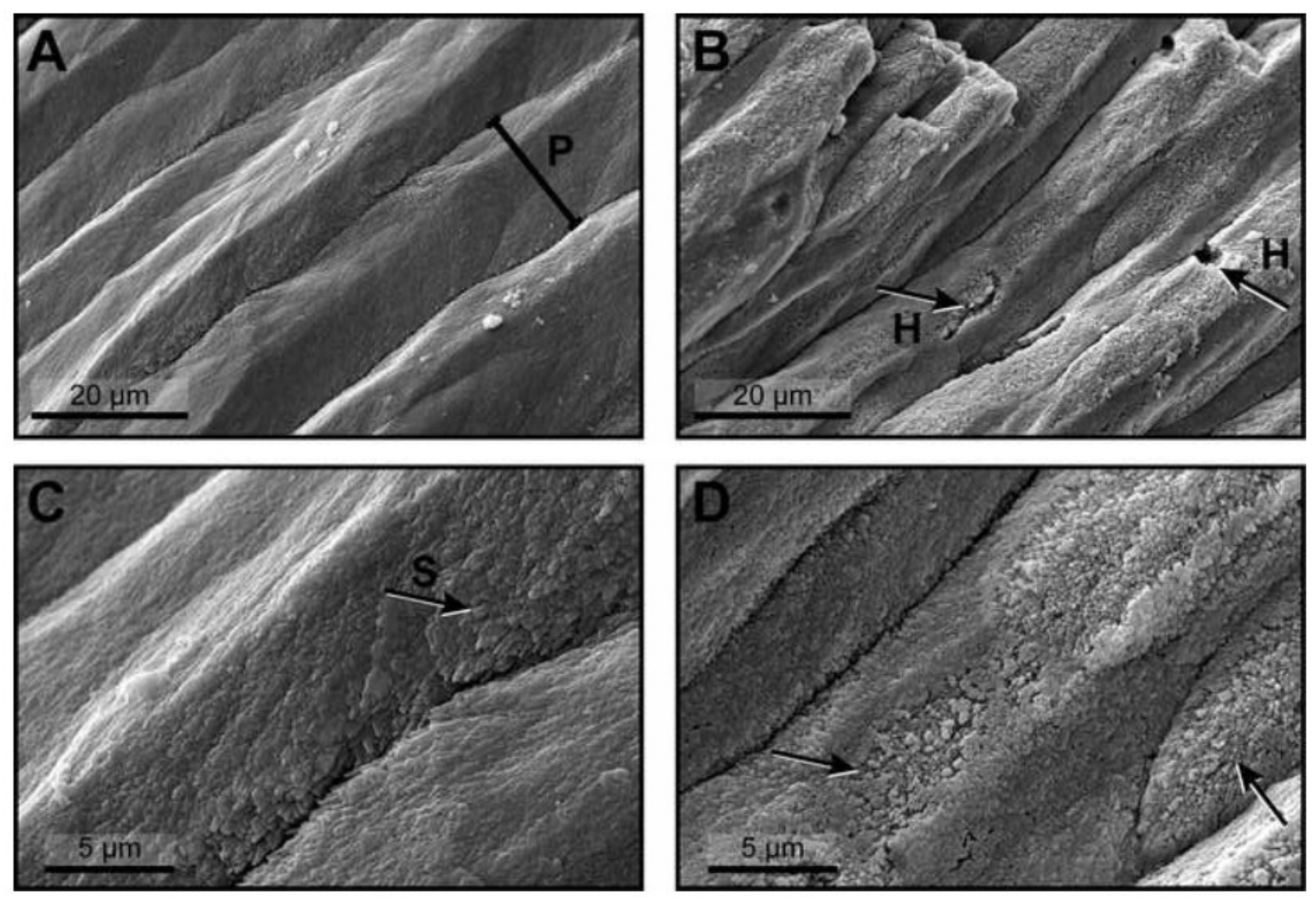

Fig. 6 


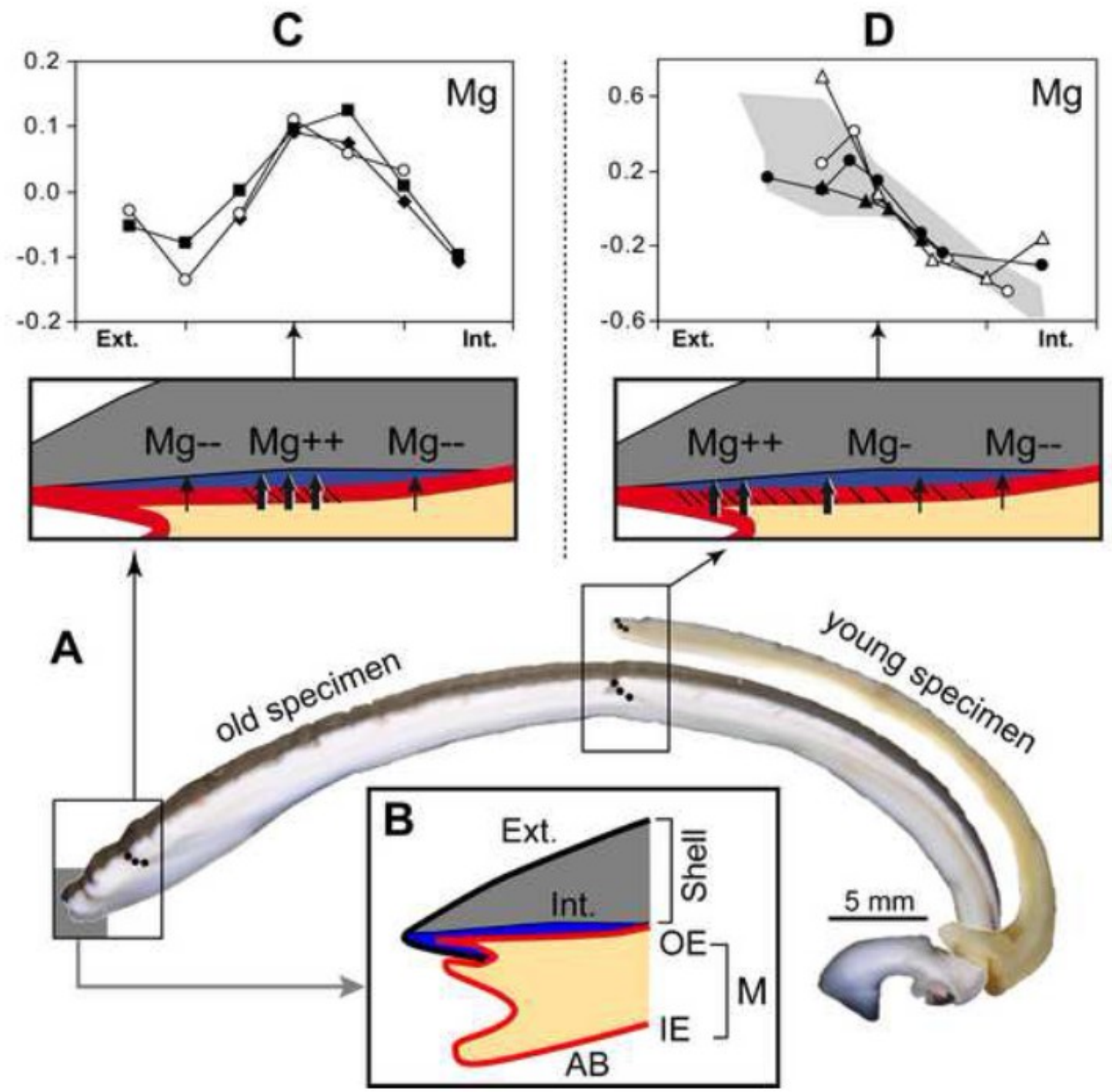

Fig. 7 